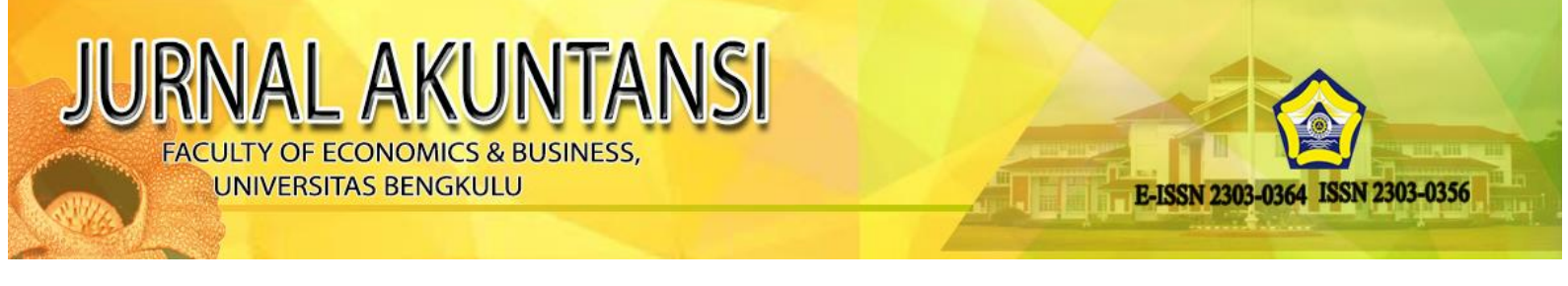

\title{
PENGARUH TUJUAN PENGGUNAAN ANGGARAN TERHADAP SENJANGAN ANGGARAN DENGAN PARTISIPASI ANGGARAN DAN PENEKANAN ANGGARAN SEBAGAI VARIABEL MEDIASI
}

\author{
Yeyen Pratiwi ${ }^{1}$ ), Lisa Martiah Nila Puspita²) \\ Fakultas Ekonomi Dan Bisnis, Universitas Bengkulu \\ yeyenpratiwi@gmail.com ${ }^{\text {l) }}$, lisaamartiahnpuspta@gmail.com ${ }^{2)}$
}

\begin{abstract}
This study to examine the effect of purpose of budget use on the budgetary slack, where budget participation and budget emphasis as a mediating variable. The sample in this study was 70 managers consisting of the financial managers, marketing managers and other managers. This study is an empirical research with quantitative approach using primary data. The analytical tool used in this research is descriptive and inferential statistics with SmartPLS version 3.0. This results of this study indicate that the purpose of budget use has a positif effect on budgetary slack. The effect of purpose of budget use on budgetary slack also positively mediated by budget participation and budget emphasis.
\end{abstract}

Keyword: Purpose of Budget Use, Budgetary Slack, Budget Participation, Budget Emphasis

\section{PENDAHULUAN}

Di dalam persaingan usaha yang semakin ketat ini, perusahaan harus mampu mempertahankan kualitas perusahaan untuk tetap bertahan hidup. Untuk bertahan hidup, perusahaan harus mampu bekerja dengan efektif dan efisien serta harus memikirkan strategi yang telah dirancangnya. Perubahan lingkungan bisnis mendorong perusahaan untuk terus melakukan perubahan-perubahan yang inovatif. Hal ini mendorong manajemen untuk menyusun perencanaan yang tepat agar dapat berkembang dan bersaing. Salah satu komponen penting dalam perencanaan adalah anggaran.

Neely, Sutcliff, dan Heyns (2001) dalam Schoute \& Wiersma (2011) berpendapat bahwa proses penganggaran tidak penting dan tidak memberikan nilai positif pada perusahaan dimana hanya akan memakan waktu dan biaya dan hanya memberikan sedikit nilai tambah dalam meningkatkan kinerja perusahaan. Sedangkan peneliti lain mengemukakan bahwa penganggaran adalah hal penting yang merupakan bagian yang tak terpisahkan dari proses perencanaan dan pengendalian perusahaan ketika anggaran tersebut dapat dijalankan dengan benar (misalnya, Covaleski et al, 2003; Hansen, Otley, dan Van der Stede, 2003; Merchant dan Van der Stede, 2007 dalam Schoute \& Wiersma (2011). Kedua pendapat yang berbeda itu tentu memberikan perdebatan tentang penggunaan anggaran pada sebuah perusahaan.

Dalam proses anggaran itu sendiri, terdapat beberapa hal yang mungkin akan terjadi. Diantara hal tersebut adalah kemungkinan terjadinya senjangan anggaran. Senjangan anggaran adalah suatu tindakan dimana manajer melebihkan kemampuan produktif dengan mengestimasikan pendapatan lebih rendah dan biaya lebih tinggi sehingga anggaran yang disusun lebih mudah untuk dicapai dengan tujuan dapat meningkatkan kinerjanya. Dalam 
lingkup senjangan anggaran terdiri dari dua yaitu senjangan anggaran itu sendiri dan tujuan senjangan. Namun dalam penelitian ini lebih ditekankan pada senjangan anggaran itu sendiri.

Proses penyusunan anggaran melibatkan banyak pihak, mulai dari manajamen tingkat atas sampai manajemen tingkat bawah yang sering disebut dengan partisipasi anggaran. Partisipasi anggaran diharapkan mampu memberikan pengaruh positif terharap target anggaran yang disusun, karena dengan terlibatnya manajer sehingga tahu dan mampu sebesar apa anggaran yang ditetapkan akan dicapainya. Namun karena karakter dan perilaku manusia yang berbeda-beda, partisipasi anggaran dapat berpengaruh negatif terhadap senjangan.

Ada dua pendapat tentang senjangan anggaran yang dipengaruhi oleh partisipasi anggaran, yaitu pendapat pertama partisipasi akan menciptakan senjangan mengemukakan bahwa semakin tinggi partisipasi yang diberikan pada bawahan dalam penganggaran cenderung mendorong bawahan menciptakan senjangan. Sedangkan kelompok yang tidak mendukung pendapat itu menyatakan bahwa partisipasi dapat mengurangi senjangan yang ditandai dengan komunikasi yang positif antara para manajer (Schoute \& Wiersma, 2011).

Seperti penelitian terdahulu yang dilakukan Afiani (2010) dalam (Kartika, 2010) menunjukkan bahwa partisipasi yang tinggi dalam proses penyusunan anggaran dapat menimbulkan senjangan anggaran yang tinggi pula. Namun hasil yang berlawanan ditunjukkan dari penelitian Sujana (2010) dimana hasil penelitiannya menunjukkan partisipasi yang tinggi dalam penyusunan anggaran dapat mengurangi terjadinya senjangan anggaran.

Beberapa akademisi berpendapat agar anggaran yang disusun dapat digunakan secara optimal, perusahaan harus menggunakan beberapa anggaran terutama untuk tujuan perencanaan dan motivasi, target anggaran yang optimal akan berbeda pada setiap tingkat secara signifikan. Penelitian yang dilakukan oleh Merchant dan Manzoni (1989) dalam Schoute \& Wiersma (2011) telah menunjukkan bahwa dalam prakteknya perusahaan tidak menggunakan anggaran yang berbeda untuk tujuan yang berbeda, hal tersebut menjelaskan bahwa telah adanya kompromi yang mereka lakukan pada tingkat senjangan anggaran mereka. Selain itu, penelitian yang dilakukan juga menunjukkan bahwa perusahaan cenderung menetapkan target anggaran untuk perusahaan mereka pada tingkat yang relatif mudah dicapai.

Dunk dan Nouri (1998) dalam Schoute \& Wiersma (2011) juga menemukan faktor lain yang mempengaruhi senjangan anggaran selain partisipasi manajemen. Faktor ini adalah penekanan anggaran, yang sebagian besar telah ditemukan berpengaruh negatif dengan senjangan anggaran, dan dianggap dapat digunakan perusahaan untuk mengurangi tingkat senjangan anggaran. Karena faktor tersebut juga tampaknya terkait dengan tujuan penggunaan anggaran, dalam artian bahwa kedua faktor tersebut dapat digunakan secara lebih intensif agar perusahaan menggunakan anggaran mereka dengan lebih intensif pula, baik untuk tujuan umum ataupun tertentu, dan mungkin kedua faktor ini yang memediasi hubungan antara tujuan penggunaan anggaran dan senjangan anggaran.

Penelitian ini merupakan replikasi dari penelitian yang dilakukan oleh Schoute \& Wiersma (2011) pada manajer 44 perusahaan yang terdaftar di Belanda. Dimana dalam penelitian tersebut meneliti tentang hubungan antara tujuan penggunaan anggaran dan senjangan anggaran, hasil penelitian tersebut adalah hubungan antara setiap variabel yang diteliti adalah negatif baik yang dimediasi oleh partisipasi anggaran maupun yang dimediasi oleh penekanan anggaran. Maksud hubungan antara tujuan penggunaan anggaran negatif dengan senjangan anggaran yang dimediasi oleh partisipasi anggaran yaitu semakin tinggi partisipasi anggaran maka senjangan anggaran yang terjadi semakin rendah. Dan hubungan antara tujuan penggunaan anggaran dan senjangan anggaran yang dimediasi oleh penekanan 
anggaran juga negatif, maksudnya semakin tingginya penekanan anggaran yang dilakukan oleh atasan kepada manajer semakin rendah kemungkinan terjadinya senjangan anggaran.

Dalam penelitian yang dilakukan oleh Schoute \& Wiersma (2011) tujuan penggunaan anggaran memiliki dua kelompok besar yaitu intensitas penggunaan anggaran dan tujuan penggunaan anggaran itu sendiri yang juga dikelompokkan menjadi tiga diantaranya tujuan perencanaan dan komunikasi, tujuan koordinasi dan alokasi, serta tujuan evaluasi dan motivasi. Namun dalam penelitian ini hanya menguji pengaruh tiga tujuan penggunaan anggaran terhadap senjangan anggaran dengan partisipasi anggaran dan penekanan anggaran sebagai variabel mediasi. Alasannya belum pernah adanya penelitian di indonesia yang menguji tentang pengaruh tujuan penggunaan anggaran terhadap senjangan anggaran, namun untuk penelitian yang menguji pengaruh partisipasi anggaran ataupun penekanan anggaran terhadap senjangan anggaran telah banyak dilakukan.

\section{KERANGKA TEORITIS DAN HIPOTESIS}

Untuk memperjelas dan mempermudah pemahaman penelitian, maka perlu dijelaskan suatu kerangka penelitian sebagai landasan dalam pemahaman yang dapat digambarkan sebagai berikut:

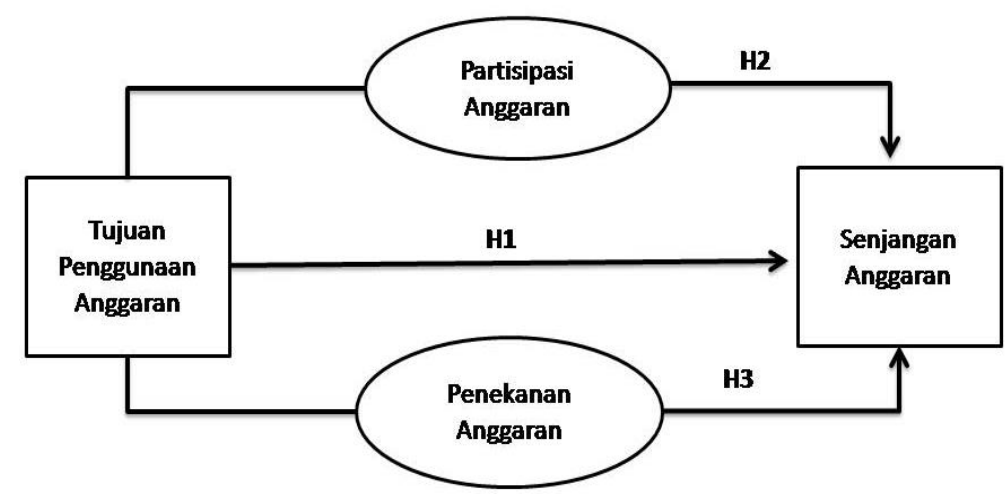

\section{Gambar 1. Kerangka Analisis}

\section{Tujuan penggunaan anggaran and Senjangan anggaran}

Penggunaan anggaran untuk tujuan perencanaan dan komunikasi adalah penggunaan anggaran untuk menerjemahkan rencana strategis jangka panjang dalam rencana jangka pendek yaitu anggaran. Ketika anggaran memiliki pengaruh yang kuat dengan rencana strategis perusahaan, hal tersebut akan memperkuat kesan bawahan bahwa strategi yang harus dikejar adalah rencana yang harus diikuti oleh seluruh karyawan. Selain itu, anggaran tersebut dapat berkomunikasi secara baik untuk seluruh karyawan.

Namun para manajer memiliki tujuan pribadi dan juga tujuan organisasi. Manajer tentu memiliki pemahaman bahwa tidak semua tindakan harus sesuai dengan rencana yang ditentukan sebelumnya, seperti anggaran. Rencana seperti itu didasarkan pada situasi yang dipercaya ada pada saat rencana tersebut diformulasikan. Dari sanalah kemungkinan terjadinya senjangan anggaran akan muncul. Oleh karena itu diperlukannya adanya koordinasi antara setiap manajer dan organisasi dalam menyelaraskan tujuan. Keselarasan tujuan (goal congruence) berarti, sejauh hal tersebut dimungkinkan, tujuan seorang manajer organisasi seharusnya konsisten dengan tujuan organisasi itu sendri. Sistem pengendalian manajemen seharusnya dirancang dan dioperasikan dengan prinsip keselarasan tujuan dalam pikiran setiap pribadi (Anthony \& Govindarajan, 2005). Sehingga jika tujuan seluruh manajer 
telah selaras dengan tujuan organisasi, diharapkan penyimpangan yang timbul seperti senjangan anggaran dapat ditekan.

Shcoute \& Wiersma (2011), mengungkapkan pengendalian adalah membandingkan antara rencana dengan pelaksanaan sehingga dapat ditentukan penyimpangan yang timbul apakah sudah menjadi tanda bahaya bagi organisasi atau belum. Penyimpangan tersebut sebagai dasar evaluasi atau penilaian prestasi para manajer. Sehingga adanya evaluasi seperti ini akan mampu memotivasi manajer untuk dapat mencapai tujuan yang telah ditetapkan. Jika tujuan yang telah ditetapkan menjadi ukuran sebuah evaluasi dan motivasi pada manajer, manajer tidak akan melakukan senjangan pada anggaran yang telah disusunnya.

H1:Tujuan penggunaan anggaran berpengaruh negatif terhadap senjangan anggaran

\section{Tujuan penggunaan anggaran, Partisipasi anggaran, and Senjangan anggaran}

Secara teoritis, partisipasi anggaran memiliki dua efek yang berlawanan pada tingkat senjangan anggaran. Pada satu sisi, partisipasi anggaran memberikan pengaruh positif terhadap senjangan anggaran. Seperti yang dikemukakan oleh Schiff \& Lewin (1968), bahwa dengan adanya partisipasi anggaran, manajemen berkesempatan untuk bernegosiasi atas target anggaran yang relatif mudah untuk dicapai. Sedangkan Webb (2002) menemukan bahwa partisipasi anggaran berpengaruh negatif terhadap senjangan anggaran karena ketika manajer secara konsisten mencapai anggaran dan mampu mengalahkan anggaran yang telah disusun dengan jumlah yang besar, mereka akan menunjukkan reputasi negatif bahwa anggaran tidak dapat diandalkan.

Dengan adanya partisipasi anggaran dimana akan mampu menekan dan menurunkan tingkat senjangan anggaran sehingga tujuan dari penggunaan anggaran yang dikelompokkan menjadi tiga tujuan itu dapat dicapai sebagaimana yang diharapkan oleh para manajer perusahaan, sehingga hubungan antara tujuan penggunaan anggaran dan senjangan anggaran negatif dengan dimediasi oleh partisipasi anggaran.

Penelitian mengenai hubungan antara ketiganya ini telah dilakukan oleh Schoute \& Wiersma (2011), dimana hubungan antara tujuan penggunaan anggaran dan senjangan anggaran menjadi negatif dengan partisipasi anggaran sebagai variabel mediasi. Namun penelitian yang dilakukan oleh Miyati (2010), partisipasi anggaran memiliki pengaruh positif terhadap senjangan anggaran yang artinya dengan adanya partisipasi anggaran, kemungkinan terjadinya senjangan anggaran menjadi lebih besar.

H2: Tujuan penggunaan anggaran berpengaruh negatif terhadap Senjangan anggaran yang dimediasi oleh Partisipasi anggaran

\section{Tujuan penggunaan anggaran, Penekanan anggaran, dan Senjangan anggaran}

Penekanan anggaran dapat mengurangi kecenderungan untuk membangun senjangan anggaran dimana akan memberikan efek negatif ketika manajer dapat mencapai target anggaran dengan jumlah lebih besar, hal tersebut menunjukkan bahwa manajer melakukan negosiasi untuk senjangan anggaran (Schoute \& Wiersma, 2011). Meskipun secara teoritis penekanan anggaran memiliki hubungan positif dan negatif terhadap senjangan anggaran, namun dalam kenyataannya hubungan keduanya adalah negatif. Dengan adanya penekanan anggaran yang memberikan hubungan negatif dengan senjangan anggaran, tentu saja hubungan antara tujuan penggunaan anggaran juga akan menjadi negatif dengan senjangan anggaran yang dimediasi oleh penekanan anggaran. Penelitian mengenai hubungan antara ketiganya ini telah dilakukan oleh Schoute \& Wiersma (2011), dimana hubungan antara tujuan penggunaan anggaran dan senjangan anggaran menjadi negatif dengan penekanan 
anggaran sebagai variabel mediasi. Untuk itu peneliti ingin menguji hubungan antara keduanya dengan hipotesis berikut:

H3:Tujuan penggunaan anggaran berpengaruh negatif terhadap Senjangan anggaran yang dimediasi oleh Penekanan Anggaran

\section{METODE PENELITIAN}

Jenis penelitian ini merupakan penelitian kuantitatif. Penelitian ini juga merupakan penelitian asosatif-kausal. Populasi dalam penelitian ini adalah seluruh manajer pada perusahaan yang berada di Indonesia. Sampel dalam penelitian 70 manajer perusahaan yang ada di Indonesia. Metode pengambilan sampel dilakukan dengan teknik purposive sampling yaitu teknik pengambilan sampel berdasarkan kriteria dengan pertimbangan tertentu, dimana pertimbangannya dalam hal ini adalah manajer yang telah memiliki pengalaman kerja minimal dua tahun dan merupakan manajer tingkat menengah dan manajer tingkat bawah. Data yang digunakan dalam penelitian ini adalah data primer. Dalam hal ini kusioner yang disebarkan berbentuk cetak dan elektronik atau kuesioner online. Website dari kuesioner online yang telah dibuat yaitu: https://goo.gl/forms/XMZeDpMTt893PosE3. Metode analisis data penelitian ini menggunakan software SmartPLS versi 3.0.m.

\section{Tabel 1. Deskripsi Kuesioner}

\begin{tabular}{l|c|c}
\hline \multicolumn{1}{c|}{ Keterangan } & Frekuensi & Persentase \\
\hline Jumlah Kuesioner yang dikirim & 78 & $100 \%$ \\
\hline Jumlah Kuesioner yang kembali & 71 & $91 \%$ \\
\hline Jumlah Kuesioner yang tidak kembali & 7 & $8 \%$ \\
\hline Jumlah Kuesioner yang tidak dapat digunakan & 1 & $2 \%$ \\
\hline Jumlah Kuesioner yang dapat digunakan & 70 & $89 \%$ \\
\hline
\end{tabular}

Sumber: Data Primer diolah 2016

Tabel 2. Statistik Deskriptif Variabel Penelitian

\begin{tabular}{|c|c|c|c|c|c|c|c|c|}
\hline \multirow[t]{2}{*}{ Variabel } & \multirow[t]{2}{*}{$\mathrm{N}$} & \multicolumn{2}{|c|}{$\begin{array}{l}\text { Kisaran } \\
\text { Teoritis }\end{array}$} & \multirow{2}{*}{$\begin{array}{c}\text { Mean } \\
\text { Teoritis }\end{array}$} & \multicolumn{2}{|c|}{$\begin{array}{c}\text { Kisaran } \\
\text { Aktual } \\
\end{array}$} & \multirow{2}{*}{$\begin{array}{l}\text { Mean } \\
\text { Aktual }\end{array}$} & \multirow{2}{*}{$\begin{array}{c}\text { Std. } \\
\text { Deviation }\end{array}$} \\
\hline & & Min & Maks & & Min & Maks & & \\
\hline $\begin{array}{l}\text { Tujuan } \\
\text { Penggunaan } \\
\text { Anggaran }\end{array}$ & 70 & 9 & 45 & 27 & 19 & 45 & 38.07 & 5.884 \\
\hline $\begin{array}{l}\text { Partisipasi } \\
\text { Anggaran }\end{array}$ & 70 & 3 & 15 & 9 & 4 & 15 & 11.26 & 2.301 \\
\hline $\begin{array}{l}\text { Penekanan } \\
\text { Anggaran }\end{array}$ & 70 & 4 & 20 & 12 & 12 & 20 & 16.77 & 2.335 \\
\hline $\begin{array}{l}\text { Senjangan } \\
\text { Anggaran }\end{array}$ & 70 & 4 & 20 & 12 & 8 & 20 & 14.27 & 2.050 \\
\hline
\end{tabular}

Variabel tujuan penggunaan anggaran memiliki nilai rata-rata teoritis 27 sedangkan untuk nilai kisaran aktualnya adalah sebesar 38.07 dan standar deviasinya sebesar 5.884. Nilai kisaran aktual minimal 19 dan maksimal 45 menunjukkan bahwa jawaban responden 
pada variabel tujuan penggunaan anggaran dikisaran 4 dan 5 yang artinya bahwa responden menilai tinggi dan sangat tinggi tentang tujuan penggunaan anggaran yang telah mereka susun. Nilai rata-rata actual diatas nilai rata-rata teoritis mengindikasi bahwa jawaban responden rata-rata menilai tinggi terhadap tujuan penggunaan anggaran yang telah mereka susun. Nilai standar deviasi sebesar 5.884 lebih kecil dari nilai rata-rata aktualnya sebesar 38.07 sehingga mengindikasikan tidak terjadinya variasi data penelitian pada variabel tujuan penggunaan anggaran.

Variabel partisipasi anggaran memiliki nilai rata-rata teoritis 9 sedangkan untuk nilai kisaran aktualnya adalah sebesar 11.26 dan standar deviasinya sebesar 2.301. Nilai kisaran aktual minimal 4 dan maksimal 15 menunjukkan bahwa jawaban responden pada variabel partisipasi anggaran dikisaran 3 dan 4 yang artinya bahwa responden menilai sedang dan tinggi tentang partisipasi pada anggaran yang telah mereka susun. Nilai rata-rata aktual diatas nilai rata-rata teoritis mengindikasi bahwa jawaban responden rata-rata menilai tinggi terhadap partisipasi anggaran yang telah mereka susun. Nilai standar deviasi sebesar 2.301 lebih kecil dari nilai rata-rata aktualnya sebesar 11.26 sehingga mengindikasikan tidak terjadinya variasi data penelitian pada variabel partisipasi anggaran.

Variabel penekanan anggaran memiliki nilai rata-rata teoritis 12 sedangkan untuk nilai kisaran aktualnya adalah sebesar 16.77 dan standar deviasinya sebesar 2.335. Nilai kisaran aktual minimal 12 dan maksimal 20 menunjukkan bahwa jawaban responden pada variabel penekanan anggaran dikisaran 4 dan 5 yang artinya bahwa responden menilai setuju dan sangat setuju tentang penekanan pada anggaran yang telah mereka susun. Nilai rata-rata aktual diatas nilai rata-rata teoritis mengindikasi bahwa jawaban responden rata-rata menilai tinggi terhadap penekanan anggaran yang telah mereka susun. Nilai standar deviasi sebesar 2.335 lebih kecil dari nilai rata-rata aktualnya sebesar 16.77 sehingga mengindikasikan tidak terjadinya variasi data penelitian pada variabel penekanan anggaran.

Variabel senjangan anggaran memiliki nilai rata-rata teoritis 12 sedangkan untuk nilai kisaran aktualnya adalah sebesar 14.27 dan standar deviasinya sebesar 2.050. Nilai kisaran aktual minimal 8 dan maksimal 20 menunjukkan bahwa jawaban responden pada variabel senjangan anggaran dikisaran 2 dan 3 yang artinya bahwa responden menilai sedang dan tinggi tentang senjangan pada anggaran yang telah mereka susun. Nilai rata-rata aktual diatas nilai rata-rata teoritis mengindikasi bahwa jawaban responden rata-rata menilai tinggi terhadap senjangan anggaran yang telah mereka susun. Nilai standar deviasi sebesar 2.050 lebih kecil dari nilai rata-rata aktualnya sebesar 14.27 sehingga mengindikasikan tidak terjadinya variasi data penelitian pada variabel senjangan anggaran.

\section{Analisis Statistik Inferensial}

\section{Outer Model (Evaluasi Model Pengukuran)}

\section{Convergent Validity (Validitas Konvergen)}

Setiap indikator dapat dikatakan valid jika memiliki nilai AVE (Average Variance Extracted) diatas 0.5 dan untuk uji reliabilitas harus memiliki nilai crombach's alpha diatas 0.6 dan nilai composite reliability diatas 0.7 . 


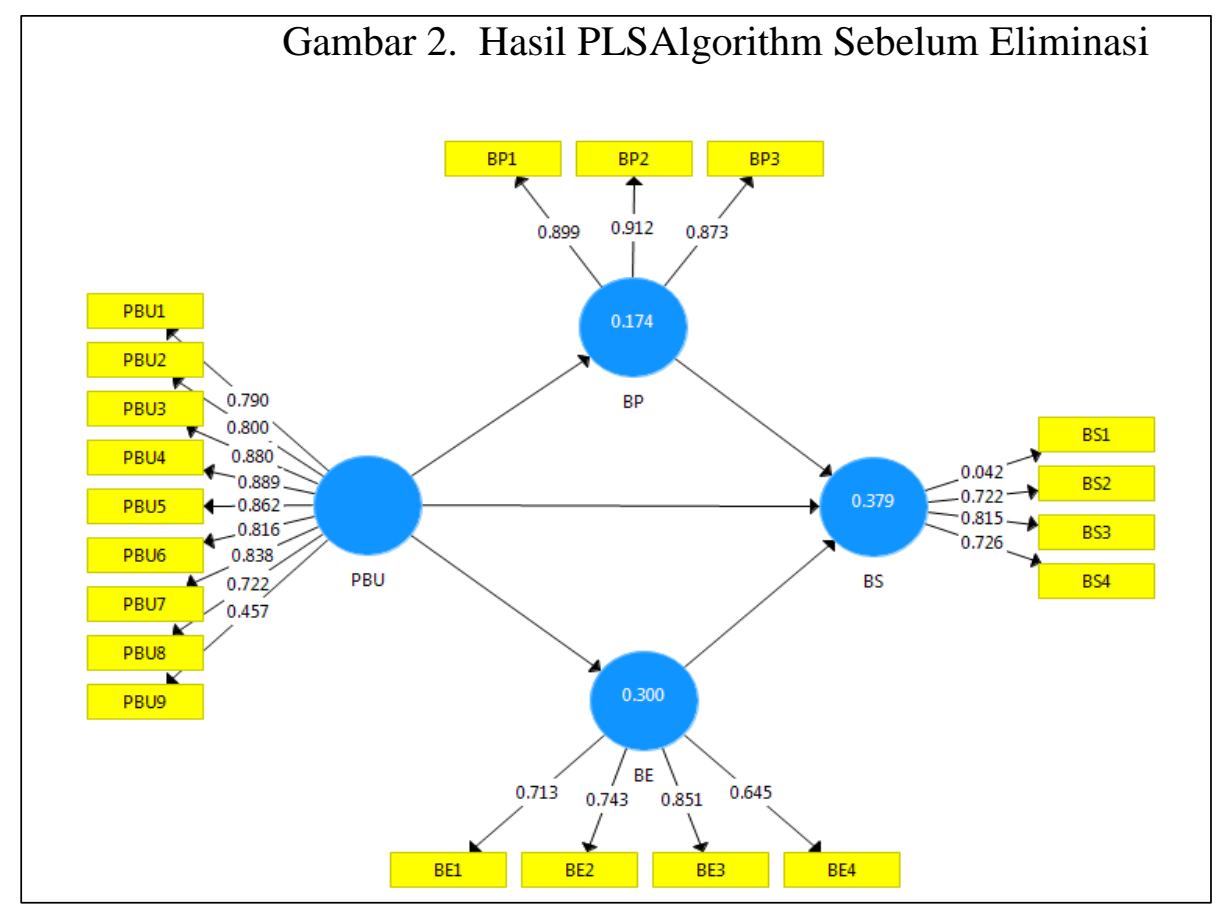

Sumber: Data primer diolah dengan PLS, 2017

Pada Gambar 2 menunjukkan bahwa tidak semua indikator dapat dikatakan reliable seperti indikator PBU9, BE4 dan BS1 yang memiliki nilai kurang dari 0.7 sehingga harus dieliminasi. Untuk indikator PBU9 hanya memiliki nilai loading factor 0.457 , untuk BE4 memiliki nilai 0.645 dan untuk BS1 hanya memiliki nilai 0.042 yang mana harus dieliminasi. Berdasarkan Gambar 2, indikator PBU9, BE4 dan BS1 yang memiliki nilai kurang dari 0.7 harus dieliminasi atau dikeluarkan dari model. Selanjutnya model akan di re-estimasi dengan mengeliminasi indikator tersebut. Untuk tampilan hasil PLSAlgorithm setelah indikator tersebut dieliminasi dapat dilihat pada gambar 4.2 berikut ini:

\section{Gambar 3. Hasil PLSAlgorithm Setelah Eliminasi 1}



Sumber: Data primer diolah dengan PLS, 2017 
Pada Gambar 3 menunjukkan bahwa semua indikator memiliki nilai diatas 0.7 kecuali indikator PBU8 yang memiliki nilai diatas 0.7 sebelum dieliminasi tetapi setelah dieliminasi memiliki nilai 0.7 sehingga harus dieliminasi atau dikeluarkan dari model. Berdasarkan Gambar 4.2 yang menjelaskan bahwa indikator PBU8 harus dieliminasi atau dikeluarkan dari model, selanjutnya model akan di re-estimasi kemali dengan mengeliminasi indikator tesebut. Pada Gambar 4.3 berikut menunjukkan tampilan hasil PLSAlgorithm setelah indikator PBU8 dieliminasi dan model di re-estimasi kembali.

Gambar 4. Kontruk yang Memenuhi Kriteria



Sumber: Data primer diolah dengan PLS, 2017

Berdasarkan Gambar 4 telah dapat disimpulkan bahwa konstruk telah memenuhi kriteria convergent validity, sehingga untuk tahapan atau uji selanjutnya indikator PBU8, PBU9, BE1, dan BS1 tidak akan diikutkan lagi di dalam model.

\section{Discriminant Validity (Validitas Diskriminan)}

Tabel 5. Nilai Discriminant Validity (Cross Loadings)

\begin{tabular}{c|c|c|c|c}
\hline & BE & BP & BS & PBU \\
\hline BE1 & $\mathbf{0 . 7 8 8}$ & 0.637 & 0.222 & 0.473 \\
\hline BE2 & $\mathbf{0 . 7 3 8}$ & 0.424 & 0.063 & 0.226 \\
\hline BE3 & $\mathbf{0 . 8 4 1}$ & 0.599 & 0.361 & 0.502 \\
\hline BP1 & 0.528 & $\mathbf{0 . 8 9 7}$ & 0.506 & 0.325 \\
\hline BP2 & 0.678 & $\mathbf{0 . 9 1 2}$ & 0.476 & 0.346 \\
\hline BP3 & 0.757 & $\mathbf{0 . 8 7 4}$ & 0.409 & 0.365 \\
\hline BS2 & 0.244 & 0.380 & $\mathbf{0 . 7 5 8}$ & 0.169 \\
\hline
\end{tabular}




\begin{tabular}{c|l|l|l|l}
\hline BS3 & 0.246 & 0.536 & $\mathbf{0 . 8 1 2}$ & 0.192 \\
\hline BS4 & 0.252 & 0.230 & $\mathbf{0 . 7 2 4}$ & 0.533 \\
\hline PBU1 & 0.306 & 0.132 & 0.297 & $\mathbf{0 . 7 5 3}$ \\
\hline PBU2 & 0.406 & 0.157 & 0.096 & $\mathbf{0 . 8 2 2}$ \\
\hline PBU3 & 0.452 & 0.289 & 0.390 & $\mathbf{0 . 8 5 7}$ \\
\hline PBU4 & 0.462 & 0.288 & 0.345 & $\mathbf{0 . 9 0 2}$ \\
\hline PBU5 & 0.482 & 0.387 & 0.412 & $\mathbf{0 . 8 9 6}$ \\
\hline PBU6 & 0.572 & 0.454 & 0.300 & $\mathbf{0 . 8 6 7}$ \\
\hline PBU7 & 0.544 & 0.435 & 0.317 & $\mathbf{0 . 8 7 7}$ \\
\hline
\end{tabular}

Sumber: Data primer diolah dengan PLS, 2017

Dari Tabel 4.5 dapat dilihat bahwa nilai loading untuk setiap indikator dari masingmasing variabel laten memiliki nilai yang paling besar dibandingkan dengan nilai loading jika dihubungkan dengan variabel laten lainnya. Hal ini berarti bahwa setiap variabel laten memiliki nilai discriminant validity yang baik dimana beberapa variabel laten memiliki nilai yang berkorelasi rendah dengan konstruk lainnya. Selanjutnya adalah melihat nilai AVE (Average Variance Extracted) dan nilai akar dari AVE untuk setiap variabel dengan korelasi antara variabel dengan variabel lainnya dalam model. Nilai AVE untuk setiap variabel harus lebih besar dari 0.5. Tabel 4.6 berikut menunjukkan hasil output nilai AVE dari model.

Tabel 6. Nilai AVE (Average Variance Extracted)

\begin{tabular}{c|c}
\hline Variabel & AVE (Average Variance Extracted) \\
\hline BE & 0.624 \\
\hline BP & 0.800 \\
\hline BS & 0.586 \\
\hline PBU & 0.731 \\
\hline
\end{tabular}

Sumber: Data primer diolah dengan PLS, 2017

Berdasarkan Tabel 6 di atas menunjukkan bahwa nilai AVE (Average Variance Extracted) untuk variabel Tujuan penggunaan anggaran adalah 0.731, Senjangan anggaran adalah 0.586, Partisipasi anggaran adalah 0.800 dan variabel Bugdet Emphasis adalah 0.624 yang artinya nilai AVE untuk masing-masing variabel laten lebih dari 0.5

Tabel 7. Discirimant Validity

\begin{tabular}{c|c|c|c|c}
\hline Variabel & BE & BP & BS & PBU \\
\hline Penekanan anggaran & $\mathbf{0 . 7 9 0}$ & & & \\
\hline Partisipasi anggaran & 0.727 & $\mathbf{0 . 8 9 5}$ & & \\
\hline Senjangan anggaran & 0.321 & 0.520 & $\mathbf{0 . 7 6 5}$ & \\
\hline Tujuan penggunaan anggaran & 0.553 & 0.385 & 0.374 & $\mathbf{0 . 8 5 5}$ \\
\hline
\end{tabular}

Sumber: Data primer diolah dengan PLS, 2017

Berdasarkan Tabel 7 di atas, untuk setiap angka yang ditebalkan adalah nilai akar AVE (Average Variance Extracted) dari setiap variabel dan angka yang tidak ditebalkan adalah nilai korelasi antar variael dengan variabel lainnya dalam model. Dilihat dari Tabel 4.7 tersebut dapat disimpulkan bahwa akar AVE semua variael lebih tinggi dari korelasi antara variabel tersebut dengan variabel lainnya. Dilihat dari hasil output Tabel 4.6 dan Tabel 4.7 diatas, dapat disimpulkan bahwa semua variabel memenuhi kriteria validitas diskriminan (Discrimant Validity). 


\section{Uji Reliabilitas}

Selain menguji validitas, dilakukan juga uji reliabilitas yang diukur dengan composite reliability dan diperkuat dengan cronbach's alpha. Untuk dapat dikatakan reliable, maka nilai cronbach's alpha harus diatas 0.6 dan nilai composite reliability harus diatas 0.7 .

Tabel 8. Cronbach's alpha dan Composite Reliabilty

\begin{tabular}{c|c|c}
\hline Variabel & Cronbach's Alpha & Composite Reliabilty \\
\hline BE & 0.722 & 0.833 \\
\hline BP & 0.875 & 0.923 \\
\hline BS & 0.655 & 0.809 \\
\hline PBU & 0.939 & 0.950 \\
\hline
\end{tabular}

Sumber: Data primer diolah dengan PLS, 2017

Berdasarkan hasil output yang terangkum dalam Tabel 8 di atas, dapat dilihat semua variabel memiliki nilai Cronbach's alpha diatas 0.6 , dan nilai composite reliability semua variabel adalah diatas 0.7 . Jadi dapat disimpulkan dari hasil output cronbach's alpha dan composite reliability tersebut bahwa semua variabel laten telah memenuhi kriteria uji reliabilitas sehingga masing-masing variabel dapat dikatan reliable.

\section{Inner Model (Evaluasi Model Struktural)}

Untuk model strukturan hasil PLS Bootstraping dalam penelitian ini dapat dilihat pada Gambar 4.5 di bawah ini:

\section{Gambar 5. Hasil PLS Bootstraping}



Sumber: Data primer diolah dengan PLS, 2017 
Tabel 9. Nilai R-Square

\begin{tabular}{c|c}
\hline Variabel & R-Square \\
\hline Senjangan anggaran & 0.339 \\
\hline
\end{tabular}

Sumber: Data primer diolah dengan PLS, 2017

Pengujian terhadap model struktural dilakukan dengan melihat nilai R-Square. Berdasarkan table 9 memperlihatkan hasil pengujian nilai $\mathrm{R}$ Square sebesar 0.339 atau 33.9\%. Interpretasi dari nilai ini adalah bahwa variabel partisipasi anggaran dan pertimbangan etika menjelaskan $33.9 \%$ variasi senjangan anggaran.

\section{Pengujian Hipotesis}

Pengujian pengaruh mediasi menggunakan prosedur yang dikembangkan oleh Baron dan Kenny (1986) dalam Gozhali dan Latan (2015) melalui tiga model.

1. Model Pertama, menguji pengaruh tujuan penggunaan anggaran terhadap senjangan anggaran dan harus signifikan pada T-Statistics lebih dari 1.668, dimana hasil bootstrapping dapat dilihat dari gambar dibawah ini:

\section{Gambar 6. Model Pertama}

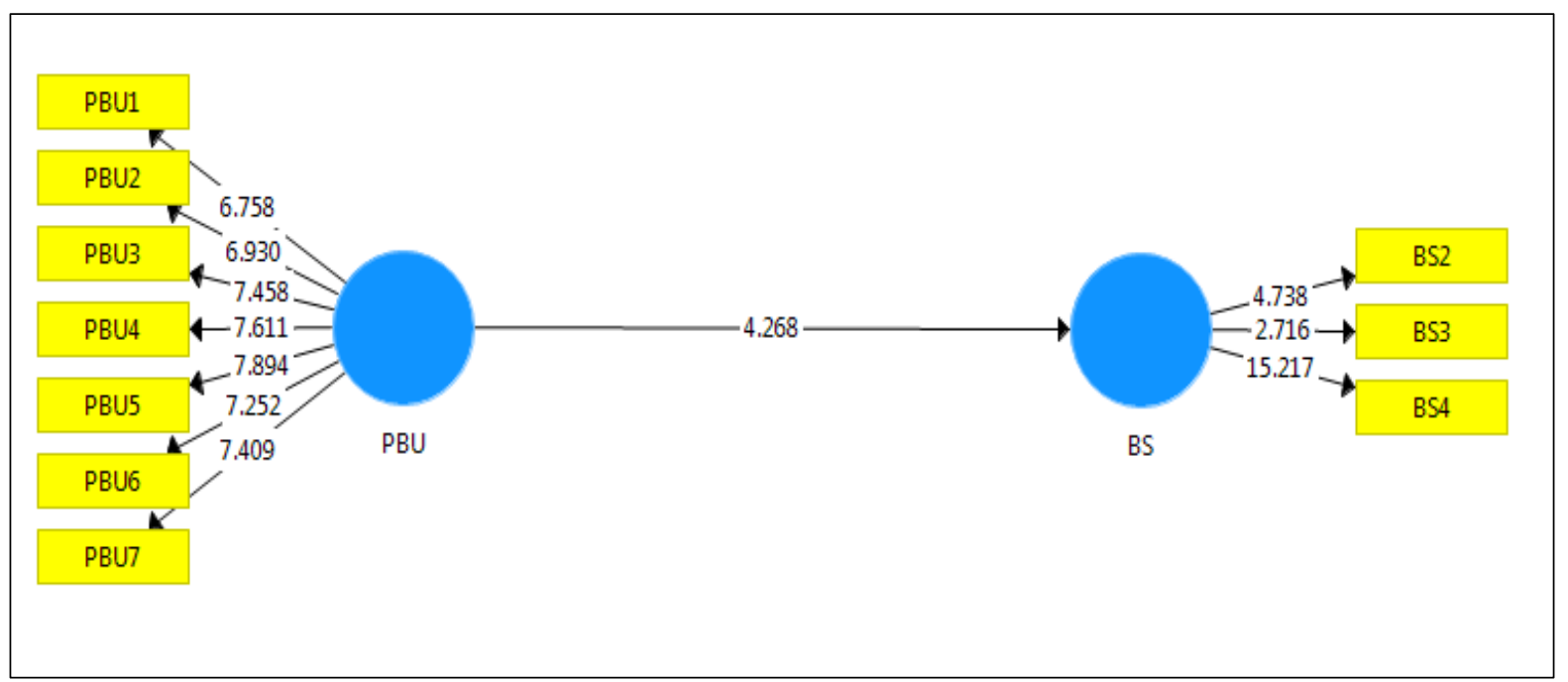

Sumber: Data primer diolah dengan PLS, 2017

Pada Gambar 6 dapat dilihat bahwa pengaruh tujuan penggunaan anggaran terhadap senjangan anggaran dengan nilai 4.268 yang mana lebih dari 1.6682. Dengan demikian nilai t-statistics PBU terhadap BS adalah 4.268, yang artinya pengaruh antar varibel tersebut adalah signifikan dengan nilai $\mathrm{P}$ Values 0.000 . Model Kedua, menguji pengaruh tujuan penggunaan anggaran terhadap partisipasi anggaran dan penekanan anggaran, dan harus signifikan pada T-Statistics lebih dari 1.668, dimana hasil bootstrapping dapat dilihat dari gambar dibawah ini: 


\section{Gambar 7. Model Kedua}

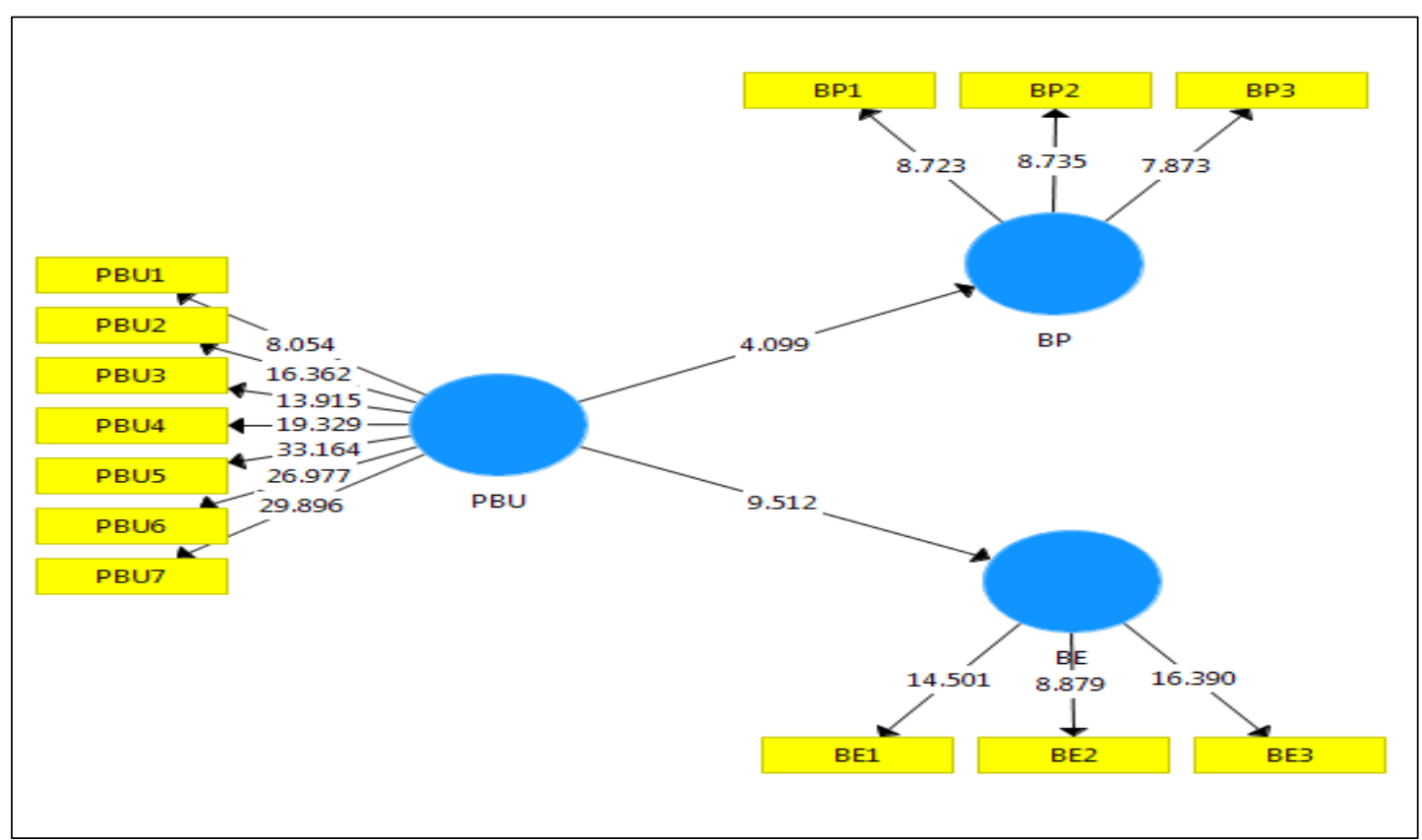

Sumber: Data primer diolah dengan PLS, 2017

Pada Gambar 7 dapat dilihat bahwa pengaruh tujuan penggunaan anggaran terhadap partisipasi anggaran memiliki nilai 4.099 yang mana lebih dari 1.6682. Dengan demikian nilai t-statistics PBU terhadap BP adalah 4.099, yang artinya pengaruh antar varibel tersebut adalah signifikan dengan nilai $\mathrm{P}$ Values 0.000 . Demikian juga dengan pengaruh tujuan penggunaan anggaran terhadap penekanan anggaran memiliki nilai 9.512, yang signifikan karena memiliki nilai yang lebih dari 1.668.

Model Ketiga, menguji pengaruh tujuan penggunaan anggaran terhadap partisipasi anggaran dan penekanan anggaran, dan harus signifikan pada T-Statistics lebih dari 1.668, dimana hasil bootstrapping dapat dilihat dari gambar 4.5. Untuk lebih jelasnya dapat dilihat pada tabel path coefficient dibawah ini, dimana pengujian simultan antara variabel PBU, BP, BE terhadap BS:

Tabel 10. Path Coefficient Model Ketiga (Mean, STDEV, t-Values)

\begin{tabular}{c|c|c|c|c|c}
\hline & $\begin{array}{c}\text { Original } \\
\text { Sample } \\
(\mathrm{O})\end{array}$ & $\begin{array}{c}\text { Sample } \\
\text { Mean (M) }\end{array}$ & $\begin{array}{c}\text { Standard } \\
\text { Deviation } \\
(\text { STDEV) }\end{array}$ & T-Statistics & P Values \\
\hline BE -> BS & 0.395 & 0.371 & 0.167 & 1.760 & 0.099 \\
\hline BP -> BS & 0.620 & 0.590 & 0.194 & 3.196 & 0.001 \\
\hline PBU -> BE & 0.553 & 0.563 & 0.073 & 7.612 & 0.000 \\
\hline PBU -> BP & 0.385 & 0.395 & 0.106 & 3.646 & 0.000 \\
\hline PBU -> BS & 0.298 & 0.299 & 0.187 & 1.596 & 0.111 \\
\hline
\end{tabular}

Sumber: Data primer diolah dengan PLS, 2017

Pada gambar 7, dengan pengujian langsung antara tujuan penggunaan anggaran terhadap senjangan anggaran, memiliki pengaruh yang signifikan yaitu sebesar 4.268 karena lebih besar dari 1.668. Namun pada tabel 10 menunjukkan bahwa tujuan penggunaan anggaran (PBU) tidak berpengaruh terhadap senjangan anggaran (BS) dengan nilai t-statistics 
sebesar 1.596. Ukuran siginifikansi keterdukungan hipotesis dapat digunakan dengan perbandingan nilai t-statistics harus lebih besar dari 1.668, maka hipotesis diterima dan juga dilihat dari nilai $\mathrm{P}$ values harus di bawah 0.05 dengan tingkat kesalahan 5 persen atau tingkat keyakinan $95 \%$. Dapat dilihat hasil dari kedua pengujian tersebut adalah berpengaruh positif, sehingga $\mathrm{H1}$ dalam penelitian ini ditolak.

Tabel diatas juga menunjukkan bahwa Tujuan penggunaan anggaran (PBU) berpengaruh siginifikan terhadap Partisipasi anggaran (BP) dengan nilai t-statistics 3.646 dan Partisipasi anggaran (BP) juga berpengaruh signifikan terhadap Senjangan anggaran (BS) dengan nilai 3.196, yang mana kurang lebih besar dari 1.668 dan nilai $\mathrm{P}$ values dari Tujuan penggunaan anggaran (PBU) terhadap Partisipasi anggaran (BP) 0.000 dan nilai $\mathrm{P}$ values Partisipasi anggaran (BP) terhadap Senjangan anggaran (BS) 0.001 yang berarti kurang dari 0.05. Pengaruh antar variabel tersebut signifikan, tetapi berdasarkan hasil pengujian tersebut pengaruh antar variabel adalah positif, dengan demikian $\mathbf{H 2}$ dalam penelitian ini ditolak.

Sedangkan untuk pengaruh Tujuan penggunaan anggaran (PBU) terhadap Penekanan anggaran (BE) berpengaruh signifikan dengan nilai t-statistics 7.612 dan nilai $\mathrm{P}$ values 0.000 , serta nilai t-statistics Penekanan anggaran (BE) terhadap Senjangan anggaran (BS) 1.760 dengan nilai $\mathrm{P}$ values 0.099 . Berarti nilai t-statistics keduanya lebih dari 1.668 dan nilai $\mathrm{P}$ values keduanya kurang dari 0.05. Sama dengan hipotesis sebelumnya yang menyatakan bahwa pengaruh antar variabel tersebut adalah negatif, namun dalam analisis data menunjukkan hasil bahwa pengaruh antar keduanya adalah positif. Berdasarkan hasil perhitungan tersebut $\mathbf{H 3}$ dalam penelitian ini ditolak.

\section{HASIL DAN PEMBAHASAN}

\section{Tujuan penggunaan anggaran dan senjangan anggaran}

Hasil ini menunjukkan bahwa tujuan penggunaan anggaran berpengaruh terhadap senjangan anggaran. Artinya jika tujuan penggunaan anggaran naik, maka senjangan anggaran juga akan naik. Jika tujuan penggunaan anggaran turun, maka senjangan anggaran juga akan turun. Maksudnya semakin para manajer tahu tentang tujuan dari penggunaan anggaran yang telah mereka susun, semakin tingi pula terjadinya senjangan atas anggaran tersebut.

Dalam penyusunan dan penggunaan anggaran, tentu seharusnya antara seluruh manajemen memiliki tujuan yang sama yaitu tujuan perusahaan. Dalam proses penggunaan anggaran yang sesuai dengan goal setting theory tentu anggaran yang telah disusun memiliki tujuan yang mana dikelompokkan menjadi tiga yaitu (a) tujuan perencanaan dan komunikasi, (b) tujuan koordinasi dan alokasi, serta (c) tujuan evaluasi dan motivasi. Namun dengan seiringnya para manajer dalam mencapai tujuan penggunaan anggaran yang telah disusun tersebut, para manajer cenderung menciptakan senjangan anggaran agar target anggaran yang telah direncanakan mudah untuk dicapai.

\section{Tujuan penggunaan, partisipasi anggaran, dan senjangan anggaran}

Semakin tinggi partisipasi para manejer baik dari manajemen tingkat atas hingga manajemen tingkat bawah akan membuat kemungkinan terjadinya senjangan anggaran juga semakin meningkat, sehingga tujuan penggunaan anggaran yang telah ditetapkan telah dibuat untuk mudah dicapai oleh para manajer tersebut. Pada teori penetapan tujuan (goal setting theory) memiliki empat macam mekanisme motivasional diantaranya tujuan mengarahkan perhatian, tujuan mengatur upaya, tujuan meningkatkan persistensi dan tujuan menunjang 
strategi dan rencana kegiatan. Sejalan dengan empat mekanisme motivasional tersebut, dengan adanya partisipasi dari seluruh manajer perusahaan baik dari tingkat atas, menengah hingga manajer tingkat bawah tentu tujuan-tujuan yang diharapkan perusahaan akan tercapai dengan baik. Dimana setiap manajer mampu mengerahkan seluruh perhatiannya pada tujuan yang yang harus dicapainya, juga seluruh upaya yang akan dilakukan oleh manajer yang berpartisipasi dalam penyusunan anggaran tersebut, tentu dengan tujuan meningkatkan persistensi mereka dan seluruh upaya yang dilakukan akan menunjang strategi dan rencana dari target yang telah mereka susun. Oleh karena itu para manajer akan berusaha untuk mencapai tujuan dari penggunaan anggaran yang telah mereka susun sendiri dengan melakukan segala cara yang dapat mereka lakukan seperti halnya menciptakan senjangan terhadap anggara yang telah mereka susun.

\section{Tujuan penggunaan anggaran, penekanan anggaran, dan senjangan anggaran}

Hipotesis yang menyatakan tujuan penggunaan anggaran berpengaruh negatif terhadap senjangan anggaran yang dimedia oleh penekanan anggaran ditolak. Semakin adanya penekanan oleh manajer puncak terhadap manajer tingkat menengah dan manajer tingkat bawah juga semakin terjadinya senjangan anggaran yang telah disusun. Dengan demikian senjangan anggaran semakin meningkat jika adanya tekanan dari manajemen puncak terhadap manajemen di bawahnya. Ketika adanya tekanan yang diberikan oleh manajemen puncak baik seperti mengawasi secara intens dan menyeluruh maupun memberikan bonus ataupun prestasi dari para manajer itu tergantung pada pencapaian target anggaran yang telah ditetapkan. Semakin tingginya tekanan yang diberikan oleh manajemen puncak kemungkinan terjadinya senjangan anggaran akan semakin meningkat pula dengan tujuan dari penggunaan anggaran itu sendiri akan tercapai dengan baik, para manajer tentu akan melakukan segala hal untuk dapat mencapai target anggaran mereka termasuk malakukan senjangan.

Pada penyusunan anggaran tentu telah ditetapkan tujuan-tujuan yang akan dicapai, yang sejalan dengan teori penetapan tujuan atau goal setting theory dimana setelah menetapkan tujuan tentu kemudian akan bekerja untuk menyelesaikan tujuan tersebut. Orientasi terhadap tujuan menentukan perilaku. Begitu pula dengan tujuan penggunaan anggaran yang telah ditetapkan, maka akan muncul perilaku-perilaku yang akan menunjang untuk tercapainya tujuan tersebut, salah satunya terjadinya penekanan anggaran. Dengan adanya penekanan anggaran oleh manajemen puncak terhadap para manajer dalam mencapai tujuan yang ditargetkan tentu, tujuan tersebut akan semakin mudah untuk dicapai ketika para manajer melakukan berbagai hal yang dapat menunjangnya seperti melakukan senjangan pada target anggaran mereka. Dengan demikian ketika para manajer telah berorientasi terhadap tujuan dari penggunaan anggaran yang mereka susun ditambah dengan adanya penekanan atas anggaran tersebut, sehingga para manajer akan semakin berusaha untuk mencapai target anggaran mereka karena kesempatan untuk menunjukkan kinerja mereka tergantung seberapa baik mereka dalam mencapai target anggaran tersebut.

\section{PENUTUP}

\section{Simpulan}

Penelitian ini masih jauh dari kata sempurna karena memiliki keterbatasan penelitian, diantaranya:

a) Penelitian tidak memfokuskan pada satu jenis perusahaan sehingga hasil penelitian ini menjadi lebih luas untuk seluruh jenis perusahaan. 
b) Dalam penyebaran kuesioner, peneliti menyebarkan secara personal kepada para manajer yang menjadi responden dalam penelitian, tidak melalui perusahaan tempat penelitian sehingga data yang didapatkan kurang banyak.

\section{DAFTAR PUSTAKA}

Alfebriano. (2013). Faktor-faktor Yang Mempengaruhi Slack Anggaran Pada PT.BRI Di Kota Jambi. e-jurnal Binar Akuntansi Vol. 2 No. 1 .

Anthony \& Govindarajan.(2005).Management Control System (Sistem Pengendalian Manajemen).Jakarta Selatan:Salemba Empat. Buku 1.

Gozhali, I., \& Latan, H. (2015). Konsep, Teknik, dan Aplikasi Menggunakan Program SmartPLS 3.0. Semarang: Badan Penerbit Universitas Dinopegoro.

Hansen, \& Mowen. (2007). Akuntansi Manajerial. Jakarta: Saolemba Empat.

Kartika, A. (2010). Pengaruh komitmen organisasi dan Ketidakpastian Lingkungan Dalam Hubungan Antara Partisipasi Anggaran dan Senjangan Anggaran.Skripsi tidak dipublikasikan.

Latuheru, B. P. (2005). Pengaruh Partisipasi Anggaran Terhadap Senjangan Anggaran dengan Komitmen Organisasi sebagai Variabel Moderasi.Skripsi tidak dipublikasikan.

Locke, E \& Lathan, P. G. (1990). A Theory of Goal Setting \& Task Performance. New Jersey: Prentice Hall.

Miyati. (2014). Pengaruh Partisipasi Anggaran Terhadap Budgetary Slack Dengan Pertimbangan Etika Sebagai Variabel Moderasi.Skripsi tidak diterbitka.Yogyakarta: Universitas Negeri Yogyakarta

Munandar, M. (2001). Budgeting. Yogykarta: BPFE.

Nafarin, M. (2007). Penganggaran Perusahaan. Jakarta: Salemba Empat.

Putri, A. D. (2010). Pengaruh Partisipasi Penganggaran terhadap Senjangan Anggaran dengan Asimetri Informasi dan Komitmen Organisasi sebagai Variabel Moderasi pada BUMN di Kota Padang.Skripsi tidak dipublikasikan.

Schoute, M., \& Wiersma, E. (2011). The Relationship Between Purposes of Budget Use and Budgetary Slack. Advances in Management Accounting , 76.

Sugiyono. (2010). Metode Penelitian Kombinasi (Mixed Methods). Bandung.

Sujana, I. K. (2010). Pengaruh Partisipasi Anggaran, Penekanan Anggaran, Komitmen Organisasi, Asimetri Informasi, dan Ketidakpastian Lingkungan terhadap Budgetary Slack.Skripsi tidak dipublikasikan. 
Susanto, Y. K. (2009). Intensitas Kompetisi Pasar dan Buget Emphasis Pada Hubungan Antara Partisipasi dan Senjangan Anggaran. Jurnal Akuntansi dan Keuangan Indonesia Vol. 6 No. 2

Tania, M. R. (2016). Pengaruh Partisipasi Anggaran terhadap Slack Anggaran Dengan Asimetri Informasi Sebagai Variabel Intervening.Skripsi tidak diterbitkan.Semarang: Universitas Diponegoro. 